\title{
Retrospects and Prospects of Agricultural Finance by Commercial Banks in Kurnool District of Andhra Pradesh
}

\author{
Dr. T. Bhargavi Hrishikesh ${ }^{1}$, Dr. G. Ramakrishna Reddy ${ }^{2}$ \\ ${ }^{l}$ (M.B.A. Department, S.R.K.P.G.College,Nandyal, Kurnool Disrict, India) \\ ${ }_{2}^{2}$ (M.Com. Department, S.R.K.P.G.College,Nandyal, Kurnool District, India)
}

\begin{abstract}
This article starts with the background of the problem, on the basis of the identified issues; objectives were drawn to prosecute a fresh study in the study region. An attempt has been made to cover the retrospective study under the heads of CBs and agriculture finance, rural credit format in India, priority sector(PS) and agricultural finance, statistical profile of priority sector and agricultural finance by CBs both at aggregate and disaggregate level. The SR got the lion's share in PS lending. Andhra Pradesh has achieved the highest share not only in SCBs advances to priority sectors in SR but also in the disbursement under RIDF. SHGs Bank Linkage programme succeeded well in AP, besides distress among farmers is also higher. The central government has identified suicide prone districts in AP. The study felt the disagreement between the higher statistical share in agricultural finance and farmers' distress in the same state. An attempt has been made to analyze the farmers' perceptions relating to agricultural finance by employing quantitative tools viz., ANOVA and Chi Square tests. Suggestions for the policy makers and avenues for further research to the scholars' who would like to undertake research in this area are also mentioned.
\end{abstract}

Key words: Priority sector, credit delivery, structural anomalies, financial constraints, farm crisis.

\section{Introduction}

The Indian Financial System is quite old with a rich and varied evolutionary experience. The existing literature on agricultural credit in general and agency wise institutional credit in particular identified many problems and suggested many measures and policy reforms. The outcomes are in the form of increase in flow of credit to agriculture by setting targets for all agencies, mobilization of the shortages to different agencies that work for infrastructure development, fine tuned credit packages for farmers like KCC, Agriculture Insurance, Farm Mechanization and subsidy in thrust areas of agriculture.

\subsection{Statement of the Problem}

Many Commercial Banks (CBs) have been lending both direct and indirect finance to agriculture. Regional Rural Banks (RRBs) that are sponsored by CBs and Cooperative Banks are working for agriculture and rural development. Many private sector banks tend to invest the funds in Rural Infrastructure Development in attaining the statutory norm of 40 percent of net bank credit to the priority sector. Even though this indirect finance promotes the infrastructure facilities and services in rural areas the poor farmer are unable to acquire these services due to financial constraints. Thus agricultural credit delivery mechanism in India is loosely integrated and not reaching the target beneficiaries. Risks are heavy in agriculture that hampers the productivity and mispricing of the output thereby dent to their revenue. Schemes that tried to integrate the mechanism of insuring yields and market risks to protect the interests of the farmers remained in nascent stage.

\subsection{Profile of the Kurnool District}

Kurnool District has good agricultural infrastructure like the Agriculture Research Station, Agriculture College, Krishi Vignana Kendra (KVK). Sona Masuri, a paddy variety grown in this district is very popular in and out of the state. In Kurnool District of Andhra Pradesh, agriculture sector with paddy, oil seeds, jowar and pulses plays a dominant role in the districts economy. Fruits, vegeTABLEs and spices are also cultivated in significant area. Animal husbandry especially diary, sheep and goat rearing have good acceptance in this district. The role of RIDF is significant in the district's infrastructure development. Three well performing revenue divisions viz., Adoni, Kurnool and Nandyal. A sound banking network has deep rooted in this district with many public and private players. In spite of these credit farmers distress also exists. The study tries to find out the reasons for the farmers distress in this district.

\subsection{Need for the study}

It has become difficult especially for CBs to gauge and appraise the quality of agricultural loan. The study brings out the fact that banks are simply giving agriculture loan just to reach the target of priority sector lending. In India agriculture productivity is low, soil health is in danger zone and risk mitigation mechanism is 
nominal. The rural financing agencies are not vertically integrated to a complete extent at different phases in this regard. There is a need to make banks more participative through policy implementation and build a conductive environment for sustainable farming system. By traversing most of the previous studies the present study felt the research gap in this aspect and does stress the need for redefining the role of CBs in agricultural credit delivery mechanism. Accordingly objectives are framed and hypotheses are set out to test and finally conclusions are drawn.

\section{Review of Literature}

Binswanger (1988) points out that many of the IRD projects failed because they were introduced into an adverse macro-economic environment, and they suffered from a lack of government commitment, lack of profiTABLE technology, neglect of service institutions, lack of beneficiary participation and an inability to solve complex coordination problems ${ }^{1}$. Banks hesitate to finance tenant farmers/oral lessees as they do not have documentary proof of their right to till the land for raising crops or for investment purposes. Recording of tenancy and ownership rights on land is an important measure to enable access to credit. Certificates by revenue officers or a system of land cultivation certificate by the Village Panchayats or local bodies may be made accepTABLE as documentary proof for cultivating the land. ${ }^{2}$

Deteriorating soil health is a major constraint limiting productivity in agriculture. The present system of fertilizer subsidy which is based on subsidization of products rather than nutrients, contributes to the problem because there is excessive subsidy on nitrogen compared to potassium and phosphates, and no subsidy at all on micronutrients. Most farmers do not have information on the soil health of their farms and the extent of micronutrient deficiency, which varies across areas. Increased awareness of this problem is extremely important. ${ }^{3}$ Risk Management arrangements, measures to improve profitability of agriculture and effective extension services would improve the confidence of banks in financing SMFs and reduce their dependence for credit from informal sources ${ }^{4}$.

SHGs for marginal farmers could be formed exclusively so that they would be able to come together according to their convenience. Special loan packages can be offered to them during particular season to have more investment in the productive and timely agriculture activities ${ }^{5}$. Agricultural insurance is an important instrument in the strategy of risk management when properly implemented; it results in a process of identification of risks, their control, avoidance or reduction. This is obviously in the interests of insurances companies and they are generally eager to promote it. Apart from the financial interests of insurance companies, risk management has a broader social aspect as it leads to reduction in wastage of economic resources and prevents environmental degradation. ${ }^{6}$.

The NCF concludes: We should not remain silent spectators to agriculture decay. Both food and human security and national sovereignty are at stake. Overall economic growth rates have little meaning if we do not look after the economic health and survival of over 60 per cent of our population."7

Rural women are an important segment of the society because of their active participation in home and farm affairs, the extent of participation in the decision making activities in house hold, agricultural and socio-cultural affair reflect the status of women in the family as well as the society. Proper education is only way to change the image of rural women who are undervalued their work and sacrifice. ${ }^{8}$

\section{Objectives of the Study}

The main objective is split into the following sub objectives.

1. To appraise the CBs credit delivery mechanism to the agriculture sector.

2. To evaluate the norms followed by CBs to priority sector lending.

3. To critically analyze the efficacy of the National Agriculture Insurance Scheme.

4. To know and analyze farmers' perceptions on agriculture finance.

\section{Hypotheses}

The entire sketch of the investigation rests upon the following hypotheses.

1. CBs credit delivery mechanism and credit provided to agriculture sector is inadequate.

2. Performance of National Agriculture Insurance Scheme (NAIS) is not in conformity with the objectives of its establishment.

\section{Research Methodology}

To justify the retrospective aspect, the study attempts to analyze the statistical profile of agriculture finance at aggregate and disaggregates level. To cover the prospective aspects of the study, farmers and bankers perception on agriculture finance by CBs are evaluated via well structured schedules. Schedules have been prepared keeping in view of the objectives and hypotheses and tested by means of pilot study. Multi stage 
sampling technique is applied. In this district four mandals are selected on the basis of familiarity and accessibility. The details of the sampling in four mandals are Nandyal(140), Panyam(140), Bandiatmakur(108) and Gadivemula (108). Farmers' perceptions are attitudinal in nature and basically it depends upon farmers' category. So out of four mandals 100 samples are drawn from each of the five categories viz., marginal, small, semi medium, medium and large. The total sample size (n) therefore forms 500. Some important and unique problems faced by farmers and bankers are discussed in direct personal investigation in the form of case studies.

\section{CBs and Agriculture Finance}

In pre-independence period systematic assistance to farmers was Land Improvement Act 1883 and Agricultural Loans Act 1884. The advent of Cooperative Institutions in 1904 gave some respite to the farmers. Nationalization of RBI in 1951, establishment of SBI and ICICI in 1955 and nationalization of CBs were the major landmark events after independence. To strengthen the rural financing system Service Area Approach, Lead Bank Scheme were introduced. Committee to Review Arrangements for Institutional Credit for Agriculture and Rural Development (CRAFICARD) recommendations on working of the lead bank scheme were implemented with some modifications.

\subsection{Rural credit format in India}

In India land related problems especially lack of legal tenancy rights are the main reason that hampers the agricultural productivity. The study noted the deep-rooted presence of money lenders in the rural credit structure. Farmers approach money lenders for their consumption needs, not by choice, but by compulsion. Farmers' knowledge in money lending laws is very poor.

Priority Sector and Agricultural Finance: A Retrospective Analysis

\subsection{Sectoral Deployment of Gross Bank Credit}

The targets and sub-targets set under priority sector lending for domestic and foreign banks operating in India are 40 percent of Net Bank Credit (NBC) and 32 percent of NBC for public and private sector banks respectively. As per the priority sector lending norms, total advances to agriculture sector should be 18 percent.

The sectoral deployment of gross bank credit to agriculture from 1996-97 to 2009-10 ranges from 11.0 percent to 13.5 percent (TABLE 1). All India Debt and Investment Survey and NSSO, 2010 disclose sources of non-institutional credit decreased from 92.7 percent in 1951 to 29.7 percent in 2010. According to the RBI sources these farmers share could not exceed not even 30 percent of the total loan disbursement for the past two decades.

Table 3.1.5: Sectoral Deployment of Gross Bank Credit from 1996-97 to 2009-10(Rupees crore)

\begin{tabular}{|c|c|c|c|c|c|c|c|c|}
\hline Years & $\begin{array}{c}\text { Gross Bank } \\
\text { Credit }\end{array}$ & $\begin{array}{c}\text { Priority } \\
\text { Sector }\end{array}$ & $\overline{\underbrace{}_{0}}$ & 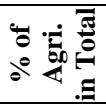 & SSI & $\begin{array}{c}\text { Other } \\
\text { Priority } \\
\text { Sectors }\end{array}$ & Industry & $\begin{array}{c}\% \text { of } \\
\text { Industry } \\
\text { in Total }\end{array}$ \\
\hline 1996-97 & $2,58,991$ & 84,880 & 31,442 & 12.1 & 35,944 & 17,494 & 102,604 & 39.62 \\
\hline $1997-98$ & $3,00,283$ & 99,507 & 34,869 & 11.6 & 43,508 & 21,130 & 117,350 & 39.08 \\
\hline 1998-99 & $3,42,012$ & $1,14,611$ & 39,634 & 11.6 & 48,483 & 26,494 & 130,516 & 38.16 \\
\hline 1999-00 & $4,00,818$ & $1,31,827$ & 44,381 & 11.1 & 52,841 & 34,362 & 147,319 & 36.75 \\
\hline $2000-01$ & $4,69,153$ & $1,54,414$ & 51,922 & 11.1 & 56,002 & 46,490 & 162,837 & 34.71 \\
\hline $2001-02$ & $5,36,727$ & $1,75,259$ & 60,761 & 11.3 & 57,119 & 57,299 & 172,324 & 32.11 \\
\hline $2002-03$ & $6,69,534$ & $2,11,609$ & 73,518 & 11.0 & 60,394 & 77,697 & 235,168 & 35.12 \\
\hline 2003-04 & $7,64,383$ & $2,63,834$ & 90,541 & 11.8 & 65,855 & 107,438 & 247,210 & 32.34 \\
\hline 2004-05 & $1,040,909$ & $3,81,476$ & $1,25,250$ & 12.0 & 74,588 & 181,638 & 352,304 & $\mathbf{3 3 . 8 5}$ \\
\hline $2005-06$ & $1,445,837$ & $5,09,910$ & $1,72,279$ & 11.9 & 90,239 & 247,392 & 458,808 & 31.73 \\
\hline 2006-07 & $1,848,166$ & $6,34,142$ & $2,30,398$ & 12.5 & 117,880 & 285,864 & 697,334 & 37.73 \\
\hline $2007-08$ & $2,247,437$ & $7,38,686$ & $2,73,658$ & 12.2 & 155,804 & 309,224 & 871,900 & 38.80 \\
\hline 2008-09 & $2,648,501$ & $9,15,886$ & $3,38,656$ & 12.8 & 168,997 & 408,233 & $1,054,390$ & 39.81 \\
\hline $2009-10$ & $3,088,569$ & $1,092,179$ & $4,16,133$ & 13.5 & 206,401 & 469,645 & $1,311,451$ & 42.46 \\
\hline
\end{tabular}

Source: Report on Trend and Progress of Banking in India, Various issues

\subsection{Statistical profile of priority sector and agricultural finance at disaggregate level}

The SCBs advances under priority sectors reveal that the accessibility to institutional credit is higher in the Southern Region (SR). C.D ratio (96.23 percent) is higher in SR and crossed the All India average (76.26 percent). In SR C.D ratio is in the order of Tamil Nadu -116.72 percent and Andhra Pradesh 112.87 percent. In A.P C.D.R less in districts likes Rangareddy (53.90 percent) and Chittoor (63.12 percent). C.D.R is higher in the districts like West Godavari (151.57 percent), Gunture (150.81 percent) and Prakasma (145.59 percent). AP has achieved the highest share not only in SCBs advances to priority sectors in SR but also in the disbursement under RIDF. SHGs Bank Linkage programme succeeded well in AP. Nearly 90 per cent of the SHGs are being run by the women. 
The District Credit Plan (DCP) from 2006-2011 crop loans stood at 50.4 percent in total priority sector lending whereas NABARD projections for crop loans stood at an average of 53.93 percent in total priority sector lending. A high coordination could be observed between these entities. Banks that contribute major share in credit deployment for agriculture sector are the State Bank of India, Andhra Bank, Sydicate Bank (Lead Bank of Kurnool District), Andhra Pragathi Grameena Bank, Kurnool District Credit Cooperative Bank. During 2006-11 in all these banks more than 90 percent of the agricultural accounts are exclusively operating for issuing of crop loans. During 2006-07 to 2009-10 CBs achievements against targets were in the order of 96.26 percent, 100.38 percent, 90.13 percent and 77.91 percent.

\section{Agricultural finance by CBs- Policies and Schemes}

1.7. Agriculture Debt Waiver and Debt Relief Scheme (ADWDRS), 2008.

Maharashtra stood first with 18 percent followed by AP and UP with 15.48 percent and 14.80 percent respectively. These three states alone accounts for more than 50 percent of the total waiver. All-India Debt and Investment Survey (AIDIA) and the Situation Assessment Survey (SAS) conducted by NSSO-2003, reveals that the share of money lenders in farmers outstanding debt was alarming in the states viz., Andhra Pradesh (53\%), Tramil Nadu(40\%), Rajasthan (37\%), Punjab(36\%) and Bihar(33\%).

Measures aimed at improving access to institutional credit

- To strengthen the institutional credit delivery system KCC Scheme, strengthening of Primary Agricultural Cooperative Credit Societies (PACS), Self Help Groups (SHGs) and Joint Liability Groups (JLGs) has been introduced.

- RIDF became an important instrument of regular bank funds for financing rural infrastructure. Now the scope of RIDF widened to enable utilization of loan by Panchayat Raj Institutions, SHGs, Non Government Organizations (NGOs) etc, since 1999-2000.

- To bring back the farmers to the institutional hold, debt waiver, debt relief, one-time settlement and loan reschedule are being provided. Input-intensive versus Low External Input Sustainable Agriculture (LEISA) model is developed to benefit the farmers.

- To mitigate the distress of farmers, the GOI launched a special rehabilitation package in 31 districts in the states of Maharashtra, Andhra Pradesh, Karnataka and Kerala aimed at providing viable farming and livelihood support system.

1.8. Agriculture Insurance and NAIS

National Agriculture Insurance Scheme (NAIS) scheme stared on the basis of Area Approach for widespread calamities and Individual Approach for localized calamities such as hailstorm, landslide, cyclone and floods. Agriculture Insurance Company (AIC) took over the implementation of NAIS till date. Now 10 percent subsidy is provided on the premium payable by marginal and small farmers. Farm Income Insurance Scheme was started on a pilot basis for wheat and rice during 2003-04 to provide income protection to farmers by integrating the mechanism of insuring yields as well as market risks. But it remained as pilot scheme. In 2003-04 the private sector came out with some insurance products in agriculture based on weather parameters. This scheme covers deviation in the rainfall index and extended for economic losses due to less or more than normal rainfall are paid.

\section{Analysis of Farmers' perceptions - an Empirical Analysis}

1.9. Socio-economic characteristics of farmers

From the above TABLE 2 it is inferred that there is a significant difference in the irrigated land leased out followed by irrigated land leased as between the five categories of farmers. The disparity between irrigated land leased in and leased out at high significance level confirms tenancy is highly prevailed in this district. The 'F' value for rain fed leased in is 1.572 , with the significant value is $0.180(p>0.05)$.

Table 2: ANOVA Test for Farmers Category and Land Leased In/Out

\begin{tabular}{|c|c|c|c|c|c|}
\hline \multicolumn{2}{|c|}{ Land Leased In and Leased Out } & Df & Mean Square & $\mathbf{F}$ & Sig. \\
\hline \multirow{3}{*}{$\begin{array}{l}\text { Irrigated Land Leased In and } \\
\text { Farmers Category }\end{array}$} & Between Groups & 4 & 51.84 & \multirow{3}{*}{4.685} & \multirow{3}{*}{0.001} \\
\hline & Within Groups & 495 & 11.066 & & \\
\hline & Total & 499 & & & \\
\hline \multirow{3}{*}{$\begin{array}{l}\text { Irrigated Land Leased Out } \\
\text { and Farmers Category }\end{array}$} & Between Groups & 4 & 10.368 & \multirow{3}{*}{8.495} & \multirow{3}{*}{0.000} \\
\hline & Within Groups & 495 & 1.221 & & \\
\hline & Total & 499 & & & \\
\hline \multirow{3}{*}{$\begin{array}{l}\text { Rain fed Leased In and } \\
\text { Farmers Category }\end{array}$} & Between Groups & 4 & 11.808 & \multirow{3}{*}{1.572} & \multirow{3}{*}{0.180} \\
\hline & Within Groups & 495 & 7.511 & & \\
\hline & Total & 499 & & & \\
\hline
\end{tabular}

Source: Field Survey 


\subsection{Investment Cost per acre}

The study takes only paddy crop for investment analysis on irrigated land as majority of farmers give preference to cultivate paddy. The principal investment factors are wages, seeds, fertilizers and pesticides. Apart from these four factors, an additional amount of Rs.3, 000 per acre is spent for seed bed preparation. Left skewed distribution could be observed for wages, fertilizers and pesticides. It implies that - most values are concentrated on the right (positive) of the mean with extreme values to the left (TABLE 3).

Table 3: Investment Cost of Irrigated Paddy Crop

\begin{tabular}{|c|c|c|c|c|c|c|c|}
\hline \multicolumn{2}{|c|}{ Farmers Category } & \multirow{2}{*}{$\begin{array}{l}\text { Wages } \\
3836.00 \\
\end{array}$} & \multirow{2}{*}{$\begin{array}{l}\text { Seeds } \\
1452.00\end{array}$} & \multirow{2}{*}{$\begin{array}{r}\text { Fertilizers } \\
4452.00\end{array}$} & \multirow{2}{*}{$\begin{array}{r}\text { Pesticides } \\
2588.00\end{array}$} & \multirow{2}{*}{$\begin{array}{r}\begin{array}{c}\text { Organic } \\
\text { Fertilizer }\end{array} \\
784.00\end{array}$} & \multirow{2}{*}{$\begin{array}{r}\begin{array}{c}\text { Organic } \\
\text { Pesticides }\end{array} \\
524.00\end{array}$} \\
\hline \multirow{3}{*}{ Marginal } & Mean & & & & & & \\
\hline & SD & 1999.57 & 1192.27 & 2297.85 & 1339.48 & 778.85 & 988.12 \\
\hline & Skewness & -1.25 & 1.21 & -1.33 & -1.30 & 0.33 & 3.77 \\
\hline \multirow{3}{*}{ Small } & Mean & 3644.00 & 1580.00 & 4288.00 & 2256.00 & 1740.00 & 732.00 \\
\hline & SD & 2123.29 & 1704.66 & 2480.52 & 1352.31 & 1859.29 & 942.69 \\
\hline & Skewness & -1.03 & 2.33 & -1.07 & -0.88 & 1.65 & 1.85 \\
\hline \multirow{3}{*}{$\begin{array}{l}\text { Semi } \\
\text { Medium }\end{array}$} & Mean & 6376.00 & 1744.00 & 6732.00 & 3144.00 & 1424.00 & 324.00 \\
\hline & SD & 1534.86 & 1118.47 & 1852.05 & 735.30 & 851.99 & 436.03 \\
\hline & Skewness & -2.74 & 2.39 & -2.10 & -3.02 & -0.25 & 0.89 \\
\hline \multirow{3}{*}{ Medium } & Mean & 5732.00 & 1296.00 & 5992.00 & 2376.00 & 1524.00 & 496.00 \\
\hline & SD & 3021.50 & 907.20 & 3091.33 & 1368.71 & 1350.28 & 629.56 \\
\hline & Skewness & -1.17 & 0.64 & -1.34 & -0.71 & 0.68 & 1.09 \\
\hline \multirow{3}{*}{ Large } & Mean & 7420.00 & 2124.00 & 7548.00 & 3500.00 & 1760.00 & 520.00 \\
\hline & SD & 2347.75 & 3428.26 & 2296.97 & 1435.20 & 1218.38 & 844.23 \\
\hline & Skewness & -2.45 & 3.13 & -2.86 & -1.01 & 0.98 & 2.85 \\
\hline \multirow{3}{*}{ Total } & Mean & 5401.60 & 1639.20 & 5802.40 & 2772.80 & 1446.40 & 519.20 \\
\hline & SD & 2683.04 & 1918.95 & 2739.99 & 1353.47 & 1316.31 & 802.87 \\
\hline & Skewness & -0.88 & 4.40 & -1.20 & -0.95 & 1.50 & 2.91 \\
\hline
\end{tabular}

Source: Field Survey

From ANOVA TABLE 4, it is observed that the ' $F$ ' values for wages, fertilizers, pesticides and organic fertilizers are 52.31, 33.945, 17.373 and 9.723 respectively. The corresponding significant value for these four variables is 0.000 with high significance.

Table 4: ANOVA Test for Farmers Category and Paddy Crop Inputs usage

\begin{tabular}{|c|c|c|c|c|c|}
\hline \multicolumn{2}{|c|}{$\begin{array}{c}\text { Inputs Cost of Paddy Crop } \\
\text { (Irrigated Land) }\end{array}$} & Df & Mean Square & $\mathbf{F}$ & Sig. \\
\hline \multirow{3}{*}{ Wages and Farmers Category } & Between Groups & 4 & $2.67 \mathrm{E}+08$ & \multirow{3}{*}{52.31} & \multirow{3}{*}{0.000} \\
\hline & Within Groups & 495 & 5100761.21 & & \\
\hline & Total & 499 & & & \\
\hline \multirow{3}{*}{ Seeds and Farmers Category } & Between Groups & 4 & $1.01 \mathrm{E}+07$ & \multirow{3}{*}{2.77} & \multirow{3}{*}{0.027} \\
\hline & Within Groups & 495 & 3630862.22 & & \\
\hline & Total & 499 & & & \\
\hline \multirow{3}{*}{$\begin{array}{l}\text { Inorganic Fertilizers and Farmers } \\
\text { Category }\end{array}$} & Between Groups & 4 & $2.02 \mathrm{E}+08$ & \multirow{3}{*}{33.945} & \multirow{3}{*}{0.000} \\
\hline & Within Groups & 495 & 5939103.03 & & \\
\hline & Total & 499 & & & \\
\hline \multirow{3}{*}{$\begin{array}{l}\text { Inorganic Pesticides and Farmers } \\
\text { Category }\end{array}$} & Between Groups & 4 & $2.81 \mathrm{E}+07$ & \multirow{3}{*}{17.373} & \multirow{3}{*}{0.000} \\
\hline & Within Groups & 495 & 1619355.15 & & \\
\hline & Total & 499 & & & \\
\hline \multirow{3}{*}{$\begin{array}{l}\text { Organic Fertilizers and Farmers } \\
\text { Category }\end{array}$} & Between Groups & 4 & $1.58 \mathrm{E}+07$ & \multirow{3}{*}{9.723} & \multirow{3}{*}{0.000} \\
\hline & Within Groups & 495 & 1619432.73 & & \\
\hline & Total & 499 & & & \\
\hline \multirow{3}{*}{$\begin{array}{l}\text { Organic Pesticides and Farmers } \\
\text { Category }\end{array}$} & Between Groups & 4 & 2098720 & \multirow{3}{*}{3.316} & \multirow{3}{*}{0.011} \\
\hline & Within Groups & 495 & 632850.101 & & \\
\hline & Total & 499 & & & \\
\hline
\end{tabular}

Source: Field Survey

To study the investment cost for rain fed crops the popular crops like Jowar, Maize and Sun Flower has been taken. The investment costs for all these crops are almost same with \pm 10 percent deviation. As the cultivation practices vary from crop to crop it influences the investment cost of these rain fed crops indirectly. Only pesticides variable's skewness is negative (TABLE 5). 
Table 5: Investment Cost of Rain fed Crops (Maize, Jowar, and Sun Flower)

\begin{tabular}{|c|c|c|c|c|c|c|c|}
\hline \multicolumn{2}{|c|}{ Farmers Category } & \multirow{2}{*}{$\begin{aligned} \text { Wages } \\
1856.00\end{aligned}$} & \multirow{2}{*}{$\begin{aligned} \text { Seeds } \\
882.00\end{aligned}$} & \multirow{2}{*}{$\begin{array}{r}\text { Fertilizers } \\
1662.00\end{array}$} & \multirow{2}{*}{$\begin{array}{r}\text { Pesticides } \\
1084.00\end{array}$} & \multirow{2}{*}{$\begin{array}{c}\begin{array}{c}\text { Organic } \\
\text { Fertilizer }\end{array} \\
440.00\end{array}$} & \multirow{2}{*}{$\begin{array}{c}\begin{array}{c}\text { Organic } \\
\text { Pesticides }\end{array} \\
380.00\end{array}$} \\
\hline \multirow{3}{*}{ Marginal } & Mean & & & & & & \\
\hline & SD & 1981.34 & 1445.50 & 1703.19 & 1070.70 & 671.50 & 1015.44 \\
\hline & Skewness & 0.44 & 3.10 & 0.28 & 0.06 & 1.24 & 3.91 \\
\hline \multirow{3}{*}{ Small } & Mean & 2208.00 & 892.00 & 2216.00 & 1432.00 & 628.00 & 524.00 \\
\hline & SD & 2005.03 & 809.00 & 1824.79 & 1096.45 & 833.89 & 1061.46 \\
\hline & Skewness & 0.34 & 0.47 & -0.05 & -0.50 & 0.78 & 3.16 \\
\hline \multirow{3}{*}{$\begin{array}{l}\text { Semi } \\
\text { Medium }\end{array}$} & Mean & 1776.00 & 648.00 & 1732.00 & 1084.00 & 460.00 & 162.00 \\
\hline & SD & 2091.31 & 829.32 & 2044.70 & 1256.15 & 733.61 & 290.34 \\
\hline & Skewness & 0.47 & 0.97 & 0.45 & 0.38 & 1.18 & 1.56 \\
\hline \multirow{3}{*}{ Medium } & Mean & 2424.00 & 872.00 & 2600.00 & 1596.00 & 900.00 & 592.00 \\
\hline & SD & 1899.98 & 717.75 & 2055.39 & 1257.70 & 840.87 & 1461.68 \\
\hline & Skewness & -0.36 & -0.09 & -0.33 & -0.35 & 0.17 & 4.32 \\
\hline \multirow{3}{*}{ Large } & Mean & 2532.00 & 996.00 & 2380.00 & 1644.00 & 620.00 & 216.00 \\
\hline & SD & 2120.93 & 888.30 & 2029.48 & 1420.51 & 670.90 & 375.71 \\
\hline & Skewness & -0.29 & 0.08 & -0.19 & -0.13 & 0.57 & 1.40 \\
\hline \multirow{3}{*}{ Total } & Mean & 2159.20 & 858.00 & 2118.00 & 1368.00 & 609.60 & 374.80 \\
\hline & SD & 2035.44 & 976.03 & 1963.34 & 1245.79 & 768.77 & 961.64 \\
\hline & Skewness & 0.12 & 2.17 & 0.06 & -0.03 & 0.77 & 5.12 \\
\hline
\end{tabular}

Source: Field Survey

From TABLE 6, it is observed that organic fertilizers are highly significant followed by inorganic pesticides, inorganic fertilizers and organic pesticides. The wages is significant values at 5 percent level of significance. The ' $F$ ' value for seed variable is 1.717 and the corresponding significance value is $0.145(\mathrm{p}>0.05)$.

Table 6: ANOVA Test for Farmers Category and Rain fed Crops Inputs usage

\begin{tabular}{|c|c|c|c|c|c|}
\hline \multicolumn{2}{|c|}{ Inputs Cost of Rain fed Crops (Jowar, Sunflower, Maize) } & Df & Mean Square & $\mathbf{F}$ & Sig. \\
\hline \multirow{3}{*}{ Wages and Farmers Category } & Between Groups & 4 & $1.13 \mathrm{E}+07$ & \multirow{3}{*}{2.755} & \multirow{3}{*}{0.027} \\
\hline & Within Groups & 495 & 4085540.202 & & \\
\hline & Total & 499 & & & \\
\hline \multirow{3}{*}{ Seeds and Farmers Category } & Between Groups & 4 & 1626800 & \multirow{3}{*}{1.717} & \multirow{3}{*}{0.145} \\
\hline & Within Groups & 495 & 947193.535 & & \\
\hline & Total & 499 & & & \\
\hline \multirow{3}{*}{$\begin{array}{l}\text { Inorganic Fertilizers and Farmers } \\
\text { Category }\end{array}$} & Between Groups & 4 & $1.67 \mathrm{E}+07$ & \multirow{3}{*}{4.449} & \multirow{3}{*}{0.002} \\
\hline & Within Groups & 495 & 3750985.051 & & \\
\hline & Total & 499 & & & \\
\hline \multirow{3}{*}{$\begin{array}{l}\text { Inorganic Pesticides and Farmers } \\
\text { Category }\end{array}$} & Between Groups & 4 & 7339200 & \multirow{3}{*}{4.876} & \multirow{3}{*}{0.001} \\
\hline & Within Groups & 495 & 1505234.747 & & \\
\hline & Total & 499 & & & \\
\hline \multirow{3}{*}{$\begin{array}{l}\text { Organic Fertilizers and Farmers } \\
\text { Category }\end{array}$} & Between Groups & 4 & 3398080 & \multirow{3}{*}{5.979} & \multirow{3}{*}{0.000} \\
\hline & Within Groups & 495 & 568326.465 & & \\
\hline & Total & 499 & & & \\
\hline \multirow{3}{*}{$\begin{array}{l}\text { Organic Pesticides and Farmers } \\
\text { Category }\end{array}$} & Between Groups & 4 & 3499120 & \multirow{3}{*}{3.871} & \multirow{3}{*}{0.004} \\
\hline & Within Groups & 495 & 903951.515 & & \\
\hline & Total & 499 & & & \\
\hline
\end{tabular}

Source: Field Survey

\subsection{Farmers Annual Average Income from different sources}

The farmers' category wise different sources of income have been calculated to assess SD. The SD for medium farmers' annual income is as high as Rs.1, 91,973.70 followed by large farmers with Rs.1, 60,846.00 and marginal farmers with Rs.1, 03,317.00. Semi medium farmer's SD is the lowest with 70.967.27 followed by small farmers with Rs.44, 629.04. Positive skewness could be found in all categories of farmers with regards to income from live stock, income from other sources (TABLE 7).

Table 7: Farmers Category wise Income from different Sources

\begin{tabular}{|l|l|r|r|r|}
\hline \multicolumn{2}{|c|}{ Farmers Category } & $\begin{array}{c}\text { Income from Live } \\
\text { Stock }\end{array}$ & $\begin{array}{c}\text { Income from Other } \\
\text { Sources }\end{array}$ & Annual Income \\
\hline \multirow{3}{*}{ Marginal } & Mean & 12300.00 & 12520.00 & 89408.00 \\
\cline { 2 - 5 } & SD & 19048.05 & 13224.16 & 103317.00 \\
\cline { 2 - 5 } & Skewness & 1.61 & 1.36 & 3.51 \\
\hline \multirow{3}{*}{ Small } & Mean & 17040.00 & 19200.00 & 104920.00 \\
\cline { 2 - 5 } & SD & 14728.46 & 21257.44 & 44629.04 \\
\cline { 2 - 5 } & Skewness & 1.36 & 1.11 & 1.34 \\
\hline
\end{tabular}


Retrospects and Prospects of Agricultural Finance by Commercial Banks in Kurnool District ....

\begin{tabular}{|l|l|r|r|r|}
\hline \multirow{3}{*}{$\begin{array}{l}\text { Semi } \\
\text { Medium }\end{array}$} & Mean & 19680.00 & 15880.00 & 147860.00 \\
\cline { 2 - 5 } & SD & 21500.71 & 20986.42 & 70967.27 \\
\cline { 2 - 5 } & Skewness & 0.90 & 1.57 & 0.48 \\
\hline \multirow{3}{*}{ Medium } & Mean & 12400.00 & 23000.00 & 265980.00 \\
\cline { 2 - 5 } & SD & 15670.86 & 22473.33 & 191973.00 \\
\cline { 2 - 5 } & Skewness & 1.11 & 0.29 & 1.64 \\
\hline \multirow{3}{*}{ Large } & Mean & 9720.00 & 42320.00 & 351840.00 \\
\cline { 2 - 5 } & SD & 11828.81 & 49297.87 & 160846.00 \\
\cline { 2 - 5 } & Skewness & 1.58 & 1.36 & 1.23 \\
\hline \multirow{3}{*}{ Total } & Mean & 14228.00 & 22584.00 & 192001.60 \\
\cline { 2 - 5 } & SD & 17211.81 & 30062.91 & 161842.00 \\
\cline { 2 - 5 } & Skewness & 1.36 & 2.37 & 1.84 \\
\hline
\end{tabular}

Source: Field Survey

From ANOVA TABLE 8, it is observed that the ' $\mathrm{F}$ ' values for income from live stock and other sources are 5.693 and 17.094 respectively. The corresponding significant value is 0.00 for both types of income. High level of significance could be observed in these variables as between the five categories of the farmers.

Table 8: ANOVA Test for Farmers Category and Sources of Income

\begin{tabular}{|c|c|c|c|c|c|}
\hline \multicolumn{2}{|c|}{$\begin{array}{c}\text { Farmers Category and Income from Live Stock and Other } \\
\text { Sources }\end{array}$} & Df & Mean Square & $\mathbf{F}$ & Sig. \\
\hline \multirow{3}{*}{ Income from Live Stock } & Between Groups & 4 & $1.63 \mathrm{E}+09$ & \multirow{3}{*}{5.693} & \multirow{3}{*}{0.00} \\
\hline & Within Groups & 495 & $2.86 \mathrm{E}+08$ & & \\
\hline & Total & 499 & & & \\
\hline \multirow{3}{*}{ Income from Other Sources } & Between Groups & 4 & $1.37 \mathrm{E}+10$ & \multirow{3}{*}{17.094} & \multirow{3}{*}{0.00} \\
\hline & Within Groups & 495 & $8.01 \mathrm{E}+08$ & & \\
\hline & Total & 499 & & & \\
\hline
\end{tabular}

\subsection{Financial Management}

The ANOVA test has been used to test on non institutional credit from different sources for five categories of farmers (TABLE 9). In all categories of farmers the debt average amount is more in input dealers and money lenders category. Input dealers are emerged as new type of money lenders. The five categories differed significantly across the five categories at the highest level of significance 0.000 . It can be derived that there is a significant difference among the five categories as between across the five categories of noninstitutional sources of income.

Table 9: Farmers Category wise Non Institutional Credit from Different Sources

\begin{tabular}{|l|l|r|r|r|r|r|}
\hline \multirow{2}{*}{\multicolumn{2}{|c|}{ Farmers Category }} & \multicolumn{5}{c|}{ Sources of Non-Institutional Credit } \\
\cline { 3 - 8 } \multicolumn{2}{|c|}{} & Land Lord & $\begin{array}{c}\text { Money } \\
\text { Lenders }\end{array}$ & $\begin{array}{c}\text { Businessmen (Input } \\
\text { Dealers) }\end{array}$ & \multirow{2}{*}{ Relatives } & \multirow{2}{*}{ Friends } \\
\hline \multirow{2}{*}{ Marginal } & Mean & 9600.00 & 44080.00 & 39000.00 & 9240.00 & 1720.00 \\
\cline { 2 - 8 } & SD & 18527.62 & 95150.67 & 53200.59 & 14349.97 & 4561.76 \\
\hline \multirow{2}{*}{ Small } & Mean & 2200.00 & 49160.00 & 30980.00 & 13400.12 & 3440.00 \\
\cline { 2 - 8 } & SD & 5699.55 & 41308.58 & 25898.20 & 26844.80 & 10130.78 \\
\hline \multirow{2}{*}{ Semi Medium } & Mean & 6000.00 & 49200.00 & 67320.00 & 16400.02 & 10600.00 \\
\cline { 2 - 8 } & SD & 18422.65 & 29565.20 & 142688.00 & 17895.30 & 17310.01 \\
\hline \multirow{2}{*}{ Medium } & Mean & 400.00 & 82000.00 & 80920.00 & 33000.00 & 13000.00 \\
\cline { 2 - 8 } & SD & 1969.46 & 69150.69 & 37095.48 & 33665.02 & 19847.91 \\
\hline \multirow{2}{*}{ Large } & Mean & 800.00 & 84480.00 & 125800.00 & 56600.00 & 20600.00 \\
\cline { 2 - 8 } & SD & 3938.93 & 84538.50 & 84682.17 & 54024.31 & 31085.42 \\
\hline \multirow{2}{*}{ ANOVA } & F & 10.483 & 8.249 & 22.049 & 35.782 & 16.348 \\
\cline { 2 - 8 } & Sig. & 0.00 & 0.00 & 0.00 & 0.00 & 0.00 \\
\hline
\end{tabular}

Source: Field Survey.

The ' $F$ ' value is 2.415 and the corresponding significance value is $0.048(p<0.05)$. There is a significant difference at 5 percent level in the perception on SHGs as a tool to extend agricultural finance as between the five categories of farmers (TABLE 10).

Table 10: ANOVA Test for Farmers Category and perception on SHGs to Extend Agricultural Finance

\begin{tabular}{|l|r|c|c|c|}
\hline \multicolumn{1}{|c|}{ Perception } & Df & Mean Square & F & Sig. \\
\hline Between Groups & 4 & 0.192 & 2.415 & 0.048 \\
\hline Within Groups & 495 & 0.08 & -- & -- \\
\hline Total & 499 & -- & -- & -- \\
\hline
\end{tabular}

Source: Field Survey 


\section{Test of Significance on Few Perceptions}

Chi-Square test has been applied on the perceptions viz., reasons for not taking warehouse receipts and reasons for farm crisis with reference to farmers' category. The test values for each perception and its association with farmers' category are obtained and tested at 5.0 percent level of significance.

Table 11: Chi Square Test for relationship between Farmers Category with the Reasons for not taking Warehouse Receipts

\begin{tabular}{|c|c|c|c|c|}
\hline $\begin{array}{l}\text { Farmers } \\
\text { Category }\end{array}$ & Reasons for not taking Warehouse Receipts & Df & Chi Square Value & $\begin{array}{l}\text { Significance (2- } \\
\text { Sided) }\end{array}$ \\
\hline \multirow{4}{*}{$\begin{array}{l}\text { Marginal / Small } \\
\text { / Semi Medium / } \\
\text { Medium / Large }\end{array}$} & Illiteracy & 4 & $18.925 \mathrm{a}$ & 0.001 \\
\hline & Indebtedness & 4 & $12.732 \mathrm{a}$ & 0.013 \\
\hline & Lack of Direct Purchase Centers & 4 & $10.218 \mathrm{a}$ & 0.037 \\
\hline & Lack of Bankers Initiatives & 4 & $12.039 \mathrm{a}$ & 0.017 \\
\hline
\end{tabular}

Source: Appendix-12.

1. Illiteracy $-\chi 2=18.925 \mathrm{a}, \mathrm{df}=4, \mathrm{p}=0.001(\mathrm{p}<0.05)$.

2. Indebtedness $-\chi 2=12.732 \mathrm{a}, \mathrm{df}=4, \mathrm{p}=0.013(\mathrm{p}<0.05)$.

3. Lack of direct purchase centers $-\chi 2=10.218 \mathrm{a}, \mathrm{df}=4, \mathrm{p}=0.037(\mathrm{p}<0.05)$.

4. Lack of bankers initiative $-\chi^{2}=12.039 \mathrm{a}, \mathrm{df}=4, \mathrm{p}=0.017(\mathrm{p}<0.05)$.

Table 12: Chi Square Test for relationship between Farmers Category With the Reasons for Farm Crisis

\begin{tabular}{|c|c|c|c|c|}
\hline $\begin{array}{l}\text { Farmers } \\
\text { Category }\end{array}$ & Farm Crisis & Df & $\begin{array}{c}\text { Chi Square } \\
\text { Value }\end{array}$ & $\begin{array}{c}\text { Significance (2- } \\
\text { Sided) }\end{array}$ \\
\hline \multirow{5}{*}{$\begin{array}{l}\text { Marginal/ Small / } \\
\text { Semi Medium / } \\
\text { Medium / Large }\end{array}$} & Low and Negative Returns & 4 & $50.033 a$ & 0.000 \\
\hline & Lack of Institutional Credit & 4 & $9.514 \mathrm{a}$ & 0.049 \\
\hline & Insufficient Subsidy Management & 4 & $24.723 a$ & 0.000 \\
\hline & Increasing Input Costs & 4 & $7.728 \mathrm{a}$ & 0.102 \\
\hline & Social and Economic Insecurity & 4 & $19.168 \mathrm{a}$ & 0.001 \\
\hline
\end{tabular}

Source: Appendix-13.

1. Low and negative returns -

$\chi 2=50.033 \mathrm{a}, \mathrm{df}=4, \mathrm{p}=0.000(\mathrm{p}<0.05)$

2. Lack of institutional credit - $\quad \chi 2=9.514 \mathrm{a}, \mathrm{df}=4, \mathrm{p}=0.049(\mathrm{p}<0.05)$.

3. Insufficient subsidy management $-\chi^{2}=24.723 \mathrm{a}, \mathrm{df}=4, \mathrm{p}=0.000(\mathrm{p}<0.05)$.

4. Increase in input costs $-\chi 2=7.728 \mathrm{a}, \mathrm{df}=4, \mathrm{p}=0.102(\mathrm{p}>0.05)$.

5. Social and economic insecurity $-\chi 2=19.168 \mathrm{a}, \mathrm{df}=4, \mathrm{p}=0.001(\mathrm{p}<0.05)$.

\section{Conclusions on Direct Personal Investigation}

Conclusions on direct personal investigation reveal that structural anomalies exist in agriculture credit format and support the research hypothesis.

1.13. Farmers' Responses

- Neither the land owner nor the tenant farmer is interested in the long term soil health management practices.

- The reasons for the farmers' insolvency are crop failure, irrational subsidy management, no punishment for the violation of ECA orders to input dealers, virtual disaster relief and inflation pushed poverty.

- There is no official recognition of tenancy, coverage of more crops and village should be considered as unit instead of mandal for claim procedure. 
- Poor farmers get caught in the debt trap due to lack of tenancy rights, low/negative returns, and volatility in input and form produce prices.

1.14. Bankers' Responses

- The guidelines are not given by the RBI and Government for good soil health management practices while sanctioning crop loan.

- Getting verification from 1B form regarding land entitlement is the main problem for sanctioning crop loan due to unavailability of updated land records.

- The impact of Debt Waiver \& Relief Scheme was severe on loan recovery.

- Financial illiteracy, financial indiscipline and lack of group cohesiveness attributes stimulate farmers to come out from banking hold.

\section{Hints to Policy Makers}

1.15. Suggestions/Hints to policy makers - at Macro Level

1. The Government of India and RBI should formulate policies and guidelines to extend the concept of social control in banking industry even for the maintenance of ideal N: P: K ratio and good soil health management practices. It is believed that banks are the right catalysts to create a momentum for the development of eco- friendly farming system.

2. Policies should be formulated by government and RBI for compulsory adoption of drip irrigation system and usage of sprinklers for obtaining agriculture finance.

3. Crop insurance should cover both crop and market risks; besides coverage of more crops and village should be considered as the unit for loss assessment. KCC linked with personal and health insurance reduces the financial burden on farmers to some extent.

4. There are a large number of PACS and primary cooperatives located in rural areas where there are no other financial service outlets. PACS could provide valuable services to the smallholders if they get access to $\mathrm{CBs}$ on an ongoing basis. RBI has already listed cooperatives as eligible institutions under the $\mathrm{BF} / \mathrm{BC}$ Model.

5. A corpus fund must be set up by the government and monitored by CBs as a risk mitigation mechanism. This fund enables banks for lending Joint Liability Groups to prevent tenant farmers dependence on informal sources of credit.

6. On line availability of $1 \mathrm{~B}$ form, database to hold the details of the tenants for official recognition of the tenancy just to avail the range of benefits. Crop loan payments should be made directly to input dealers via farmers account. This method regulates the input prices and misuse of crop loans could be eliminated.

12. Community Development programmes should be organized on the lines of Sangha Krishi where millions of women are farming nearly ten millions of land as part of Kerala's anti-poverty programme Kudumbashree where Neighborhood Groups (NHGs) are the primary unit of Kudumbashree. The NHGs are different from Self Help Groups and these are structurally linked to the local self government institutions and concentrate on local development and needs and aspirations of communities. CBs should actively engage in financing the NHGs to create food economy and setting up of backward linkages to SHGs.

13. CBs should make efforts to ensure that all farm produce is subjected to primary and if possible secondary value addition locally as a part of credit linked marketing services instead of sanctioning loans on Warehouse Receipts. These types of services stimulate the non-loan farmers to get into the banking hold.

14. As part of capacity building, the CBs should upload their crop loan details facilitating all banks to derive all types of crops total production in kharif and rabi. This updated information is very helpful to bankers to link the farmers with direct purchase centers with optimum logistics.

15. To offer credit plus services, a separate cell should be established in rural development division by CBs to join with agri-business clinics and corporate engaged in agricultural activities.

16. Problems in issuing the crop loan, crop insurance and the tenancy related issues could better be handled if the agricultural direct finance is in local hands. CBs can use the PACS as front end for their agricultural direct finance disbursement. Agro industries promotion, infrastructure development, credit linked marketing services, enhancing productivity and income are as important as direct agricultural finance. These services are directly taken up by the CBs.

1.16. Suggestions for policy makers - at Micro Level

1. On Farm Development activities are to be progressive. Banks should finance for adequate diesel retail outlets in rural areas to encourage farm mechanization.

2. Kurnool District is one of the major producers of various horticulture crops. Even fresh production also needs cold storage support. Bankers should think about the possibilities for financing more cold storage facilities. 
3. Only 32 percent of the milk produced in the district is handled by organized diary sector according to the milk union data. Bankers can take an advantage in this sector because income from livestock is one of the major sources of income for farmers.

\section{Avenues for Future Research}

The most thrust areas for future research are Agriculture Insurance, Strengthening of Primary Agriculture Credit Societies (PACS), redesigning the functions of Public Distribution System (PDS), Technical Inclusion, Financial Inclusion, Role of CBs in Credit Linked Marketing Services, Contract Farming.

$* * *$

\footnotetext{
${ }^{1}$ Binswanger Hans, “Agricultural and Rural Development: Painful Lessons”, in Carl K. Eicher and John M. Staatz., Baltimore, MD (Eds.), International Agricultural Development, Third Edition, The Johns Hopkins University Press, 1998: pp.287-299.

${ }^{2}$ Government of India, Report of the Committee on Financial Inclusion, Chairman Dr.C. Rangarajan, 2008, p.25.

${ }^{3}$ Government of India, Planning Commission, Eleventh Five Year Plan 2007-12, Volume I, Inclusive Growth, Oxford University Press, (New Delhi, 2008), p.7.

${ }_{5}^{4}$ Ranjana Kumar, "Empowering Small Farmers”, The Hindu Survey of Indian Agriculture ,2005, p.199.

5 A.Thomas, "Micro Credit and Empowerment of Marginal Farmers", in Dr.Daniel Lazar and Professor P.Palanichamy (eds.), Micro Finance and Poverty Eradication, New Delhi: New Century Publications, 2008, p.121.

${ }^{6}$ C.S.Prasad (ed.), Sixty Years of INDIAN AGRICULTURE 1947 TO 2007, New Delhi: New Century Publications, 2006, p.120.

${ }^{7}$ Ruddar Datt and K.P.M.Sundharam,, Indian Economy, New Delhi: S.Chand \& Company Ltd., 2008, p.493.

8 Dr. Baij Nath Singh, "Undervaluation of Work and Status of Rural Women: A Study", Southern Economist, Volume 44, Number 21, p. 23.
} 